\title{
Culture Dependent Examination of Commercially Available Bar Chocolates
}

\author{
S. Sheik Asraf, N. Shobi, R. Soundarya, M. Udaya Kumar
}

\begin{abstract}
In the year 2018 a report published by TechSci Research entitled "India Chocolate Market Forecast and Opportunities, 2018" reiterated that the chocolate market earnings in India has witnessed the growth rate of $21 \%$ from 2013-2018. Indian chocolate market witnessed USD 3.2 billion revenues in 2018. Indian chocolate market is divided into 4 sectors, in which bar chocolates accounts for highest share of 36\%. Hence, We had chosen to study the commercially available bar chocolates through culture dependent methods. We had selected 3 commercially available bar chocolates namely Cadbury Dairy milk, Cadbury 5 Star and Cadbury Perk. Bacteria were isolated from these 3 brands of chocolate by streak plate method. Microbiological and Biochemical assays such as Simple staining, Gram staining, Catalase test, Methyl Red test, Oxidase test, Vogus Proskaur test, Indole test, Citrate utilization test and Starch hydrolysis test were performed. The bacterial isolates were found to be Rod shaped and Gram negative. The bacterial isolates were found to be negative for all the above mentioned tests except Methyl Red and Starch hydrolysis test. Thus, these findings highlight the impending health hazard posed by the commercially available bar chocolates.
\end{abstract}

Keywords : Culture dependent, Bar chochlates, Bacteria

\section{INTRODUCTION}

During 2018 TechSci Research released a report entitled

"India Chocolate Market Forecast and Opportunities, 2018 " that confirmed the fact that the revenues of Indian chocolate market showed the annual growth rate of around $21 \%$ for the time period between the years of 2013-2018[1]. The chocolate industry is considered as the majority admired product in the food and beverage processing industry in India. In 2018, the chocolate market in India reached the revenues of around 3.2 Billion U.S. $\$$ due to the ever increasing gifting practice in India and enlargement in the overall income among the working class which has fuelled the demand for chocolate products in the country[1]. Indian chocolate market is divided into four segments in which Bar chocolates segments accounts for maximum revenue of $36 \%$ [1]. It was reported that instant chocolate puddings were found to be spoiled by Pseudomonas sp. Strain AZR1 and Klebsiella sp. Strain AZR2 due to the

Revised Manuscript Received on December 05, 2019.

* Correspondence Author

S. Sheik Asraf*, Department of Biotechnology, Kalasalingam Academy of Research and Education, Anand Nagar, Krishnankoil, India.

N. Shobi, Department of Biotechnology, Kalasalingam Academy of Research and Education, Anand Nagar, Krishnankoil, India.

R. Soundarya, Department of Biotechnology, Kalasalingam Academy of Research and Education, Anand Nagar, Krishnankoil, India.

M.Udaya Kumar, Department of Biotechnology, Kalasalingam Academy of Research and Education, Anand Nagar, Krishnankoil, India.
Azoreductase activity of the spoilage organisms [2]. The microbial spoilage of UHT-treated milk chocolate by Enterobacter sp. and Micrococcus sp has been reported [3]. We had chosen to examine the microbiota of commercially available bar chocolates through microbiological and biochemical methods. We had selected the following bar chocolates namely Cadbury's Dairy milk, 5 Star and Perk for this study. Streak plate culture method was used to isolate the pure cultures of bacteria from these 3 bar chocolates. Biochemical and Microbiological tests like Starch hydrolysis test, Citrate utilization test, Indole test, Vogus Proskaur test, Methyl Red test, Oxidase test, Catalase test, Simple staining and Gram staining was done for the bacterial isolates. Bacterial isolates were Rod shaped and Gram negative. Except for Methyl Red test and Starch hydrolysis test, the bacterial isolates were found to be negative for all the above mentioned tests. Thus, these findings highlight the impending health hazard due to the commercially available bar chocolates to the Indian consumers

\section{MATERIALS, METHODS, RESULT AND DISCUSSION}

\section{A. Bacterial isolation from commercially available chocolate bars}

Segregation of the bacterial population from commercially available bar chocolates by streaking the culture on agar plate (Table 1, Figure 1)

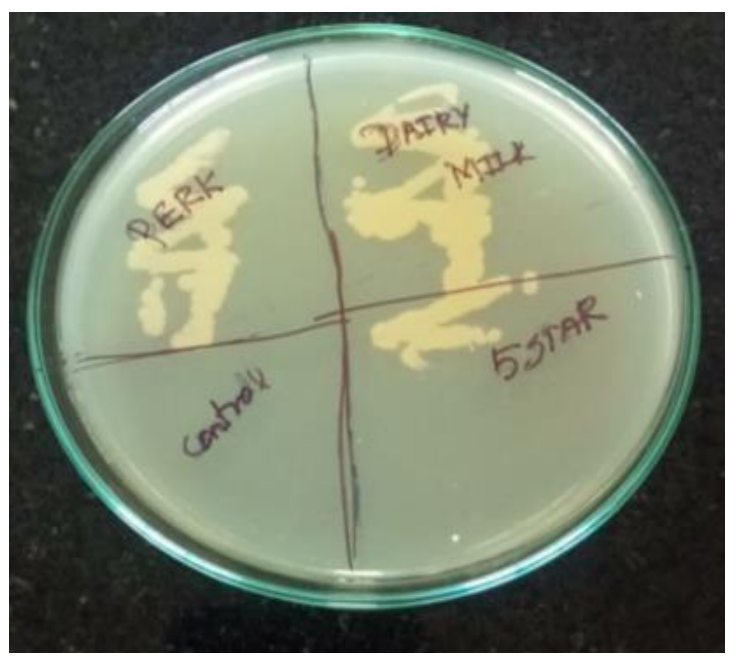

Fig. 1. Isolation of the bacteria from bar chocolates

Published By:

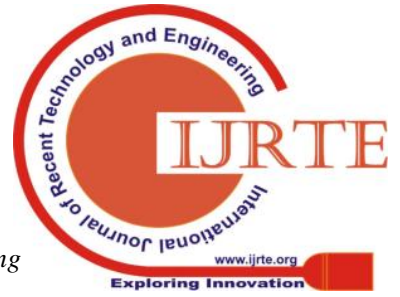


Table-I. Bar chocolates used for this study

\begin{tabular}{|c|c|c|}
\hline $\begin{array}{c}\text { Name of the bar } \\
\text { chocolates }\end{array}$ & $\begin{array}{c}\text { Date of } \\
\text { manufacturing }\end{array}$ & $\begin{array}{c}\text { Date of } \\
\text { expiry }\end{array}$ \\
\hline Cadburys' Dairy milk & October, 2018 & $\begin{array}{c}\text { October, } \\
2019\end{array}$ \\
\hline Cadburys' Five star & November, 2018 & July,2019 \\
\hline Cadburys' Perk & October, 2018 & June, 2019 \\
\hline
\end{tabular}

\section{B. Simple staining}

A loop packed with suspension of the bacterial isolates of the bar chocolates was taken on a dirt free slide and broadened and later air dried. The bacterial smear was heat fixed. Later, a drop of crystal violet was added for 15-60 S. The slide was rinsed in water, air dried and later observed under microscope. Rod shape of bacteria was observed $[4,5]$.

\section{Gram staining}

A loop packed with suspension of the bacterial isolates of the bar chocolates was taken on dirt free slide slide, spread and later heat fixed. Crystal violet was added and maintained for $60 \mathrm{~S}$ and further the bacterial smear was rinsed in water. Gram's iodine was added and the slide was left untouched for one minute. It was again washed in water and later the decolouring agent was added and it was again washed in water. Safranin was added and incubated for one minute. It was again washed in water and the glass slide was examined under microscope [6]. The bacteria isolated from the bar chocolates were found to be Gram negative (Figure 2).
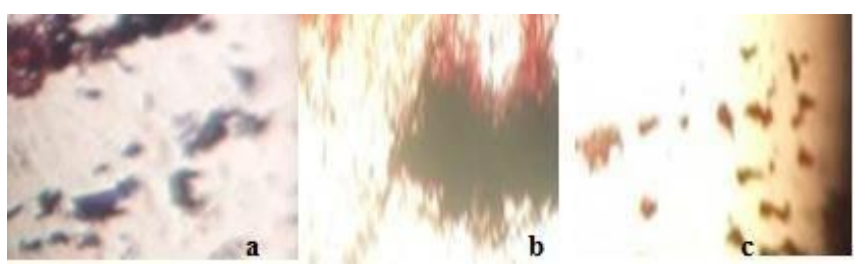

Fig. 2. Gram staining of bacterial isolates. a,b,c are the Gram staining results of bacterial isolates from Cadburys' Dairy milk, Perk and Five star respectively.

\section{Catalase test}

A dirt free glass slide was taken and few drops of suspension of the bacterial isolates of the bar chocolates were added. Later, few drops of $\mathrm{H}_{2} \mathrm{O}_{2}$ was added[7]. Evolution of oxygen was not observed indicating negative result for catalase for the bacterial isolates of the bar chocolates (Figure 3).
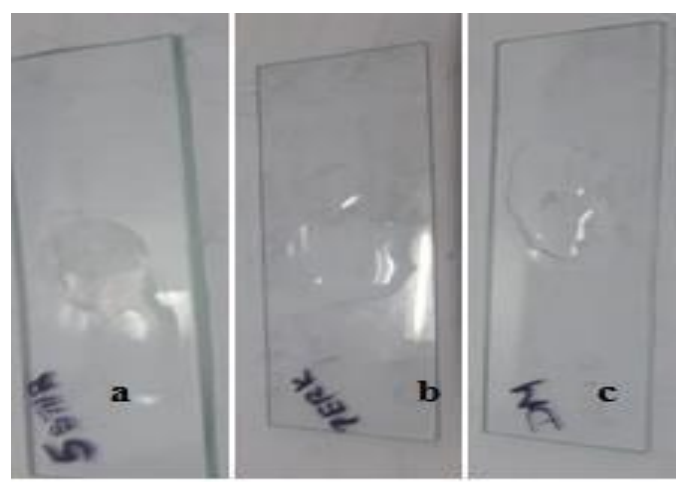

Fig. 3. Catalase test of bacterial isolates.a, b, $c$ are the catalase results of bacterial isolates from Cadburys' Five star, Perk and Dairy milk respectively.

\section{E. Oxidase test}

Amino dimethyl aniline oxalate discs were placed on the glass slide. The bacterial isolates of the bar chocolates was added using pipette to the disc [8]. There was no development of Pink/Maroon/Black color formation indicated the negative result for oxidase for the bacterial isolates of the bar chocolates (Figure 4).

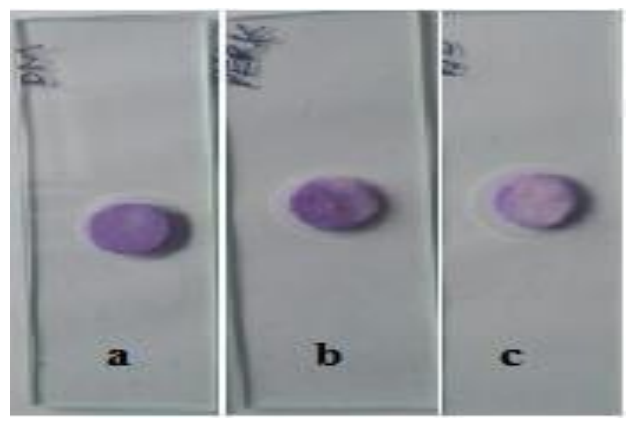

Fig. 4. Oxidase test for bacterial isolates $a, b, c$ are the oxidase test results of bacterial isolates from Cadburys' Dairy milk, Perk and Five star.

\section{F. Indole test}

The peptone broth was prepared. After autoclaving at autoclaved at $121^{\circ} \mathrm{C}, 15 \mathrm{lbs}$ for 15 minutes, the bacterial isolates of the bar chocolates was inoculated into the test tubes and later incubated. Later $1 \mathrm{ml}$ of Kovac's reagent was introduced and was shaken well [9]. No cherry red formation indicated that the bacterial isolates of the bar chocolates were found to be -ve for indole test (Figure 5). 


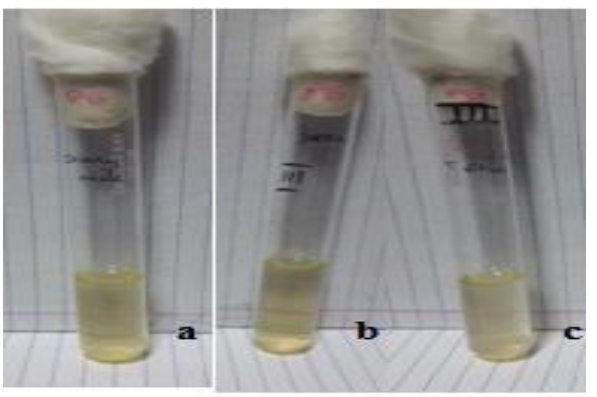

Fig. 5. Indole test for bacterial isolates a, b, $c$ are the Indole test results of bacterial isolates from Cadburys' Dairy milk, Perk and Five star.

\section{G. Methyl red test}

MR-VP broth in the test tubes were kept at $121^{\circ} \mathrm{C}$ for 15 minutes. The MR-VP broth was inoculated with the bacteria isolated from the bar chocolates and later incubated and 5-6 drops of methyl red solution was added [10]. The formation of Red color indicated positive result for methyl Red test for the isolated bacteria of the bar chocolates (Figure 6).

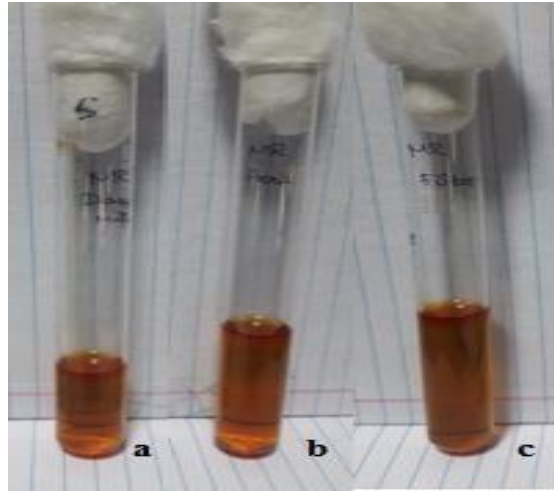

Fig. 6. Methyl Red test of the isolated bacteria. a, b, c are the test results of isolated bacteria from Cadburys' Dairy milk, Perk, and Five star.

\section{H. Vogus proskaur test}

MR-VP broth was autoclaved at $121^{\circ} \mathrm{C}, 15 \mathrm{lbs}$ for a period of 15 minutes. After sterilization, the isolates of the bacteria from the bar chocolates was introduced into the medium and were incubated. Barrit's reagent was added and mixed well[11]. The absence of deep rose color indicated the negative result for Vogus Proskaur test for the bacterial isolates of the bar chocolates (Figure 7).

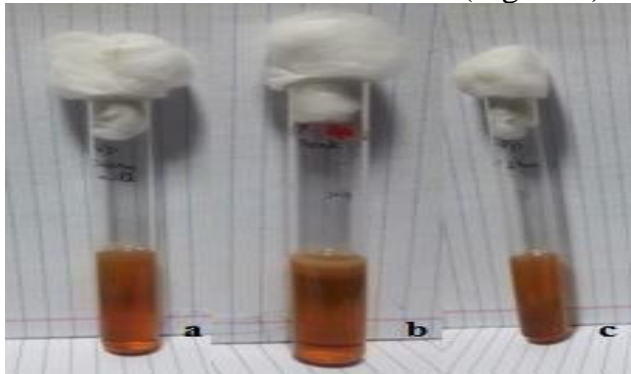

Fig. 7. Vogus Proskaur test for bacterial isolates. a, b, c are the test results of bacterial isolates from Cadburys' Dairy milk, Perk and Five star

\section{Citrate utilization test}

The simmon's citrate agar medium was prepared and later was autoclaved at $121^{\circ} \mathrm{C}, 15 \mathrm{lbs}$ for 15 minutes. The sterilized simmon's citrate agar medium were made as agar slants. The isolated bacteria of the bar chocolates were inoculated. The test tubes were incubated [12] and there was no Blue color formation. Hence, the isolated bacteria of the bar chocolates was found to be negative for citrate utilization (Figure 8).

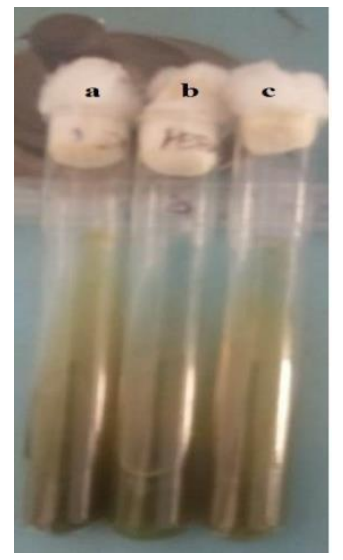

Fig. 8. Citrate utilization test of the isolated bacteria. a, b, $c$ are the test results of bacterial isolates of Cadburys' Dairy milk, Perk, Five star.

\section{J. Antibiotic disc test- Kirby bauer method}

Using sterile technique, the agar plate was inoculated with the isolated bacteria as follows: A sterile cotton swab was dipped with bacterial culture and using the swab, the entire agar surface was streaked with the bacterial culture in horizontal, vertical and edges of the petri plate to ensure heavy bacterial growth over the complete surface. The petriplate was dried for about 5 minutes. The antibiotic disc such as ampicillin, streptomycin and nitrofurantoin were placed at equal distance with forceps dipped in alcohol and flame. The antibiotic discs were gently pressed down with the wooden edge of the cotton swab [13]. The petriplates were incubated for 24 hours at $37^{\circ} \mathrm{C}$. The region of inhibition was observed around all the three antibiotic discs. (Figure 9)

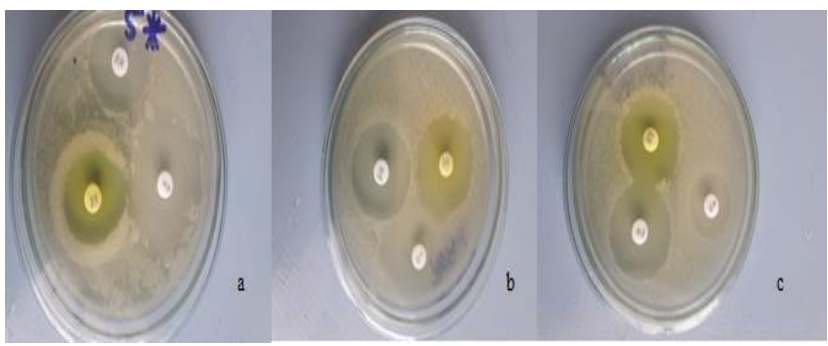

Fig. 9. Antibiotic disc test for bacterial isolates. a, b, c are the test results of bacterial isolates of Cadburys' Dairy milk, Perk, Five star.

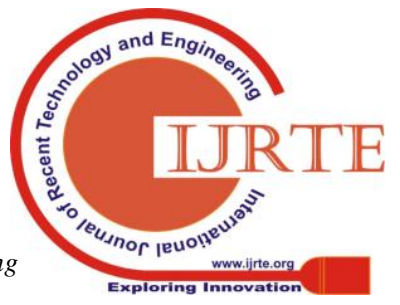




\section{K. Starch hydrolysis test}

Nutrient starch agar medium was prepared, sterilized at $121^{\circ} \mathrm{C}$ at $15 \mathrm{lbs}$ pressure for 15 minutes and dispersed into petriplates. The bacterial isolates of the bar chocolates was inoculated onto the medium and kept at $37^{\circ} \mathrm{C}$ for 24 hours. Following the incubation, the plates were flooded with lugol's iodine. The bacterial isolates were found to be positive for starch hydrolysis (Figure 10)

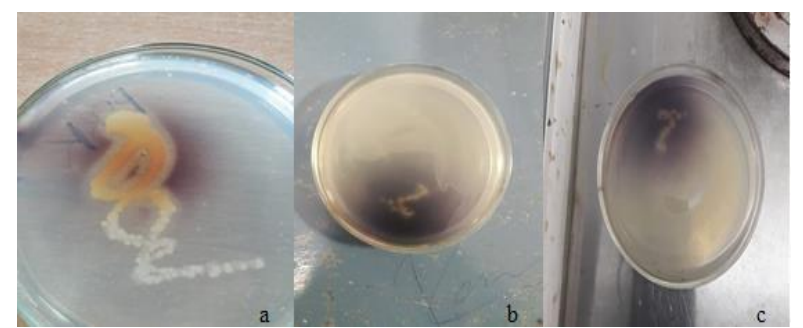

Fig. 10. Starch hydrolysis test for bacterial isolates. a, b, $c$ are the test results of bacterial isolates of Cadburys' Dairy milk, Perk, Five star.

"India Chocolate Market Forecast and Opportunities, 2018" report confirmed the fact that the Indian chocolate market revenues showed the annual growth rate of approximately $21 \%$ for between 2013-2018[1]. The chocolate industry is considered as one among the major food and beverage processing industries in India which is evident from the fact that in the year 2018, the indian chocolate market reached the revenues of approximately 3.2 Billion U.S.\$ due to increase in gifting practice and overall income among the working class in India [1]. Our study is significant to address the issue of quality of the chocolates. Our study correlates with earlier reports of chocolate puddings found to be spoiled by Pseudomonas sp. Strain AZR1 and Klebsiellasp. Strain AZR2 due to the Azoreductase activity of the spoilage organisms [2]. Our study also emphasizes the earlier report of the microbial spoilage of UHT-treated milk chocolate by Enterobacter sp. and Micrococcus sp [3].

Thus, our study highlight the impending health hazard posed by the commercially available bar chochlates to the Indian consumers.

\section{ACKNOWLEDGMENT}

The authors thank the management of KARE.

\section{REFERENCES.}

1. https://www.techsciresearch.com/news/84-india-chocolates-market-expect ed-to-cross-us-3-2-billion-by-2018.html

2. G.A. Dykes, R.G. Timm and A. Von Holy, "Azoreductase activity in bacteria associated with the greening of instant chocolate puddings." Appl.environ. microbial. vol. 60. 1994, pp. 3027-3029.

3. J.C. Antoine, and A.L Donawa, "The spoilage of uht-treated chocolate milk by thermoduric bacteria." Journal of food protection. vol. 53. 1990, pp.1050-1051.

4. I.B. Kuvaeva, and M.I.U. Troshina, "Microbiological characteristics and detection of capsular forms of bacteria of the intestinal group in confectionary produced at the candy-chocolate factories." Voprosy pitaniia. vol.4.1998, pp. 60-63.

5. R.B. Moyes, J. Reynolds, and D.P.Breakwell, "Preliminary staining of bacterial: negative stain." Current protocols in microbiology.vol. 15. 2009, pp. A-3F.

6. D. Claus, "A standardized gram staining procedure." World journal of microbiology and biotechnology.vol. 8.1992, pp. 451-452.
7. W.I. Taylor, and D. Achanzar, "Catalase test as an aid to the identification of enterobacteriaceae.” Appl.environ. microbial.vol. 24. 1972, pp. 58-61.

8. J.J. Tarrand, and D.H. Groachel, "Rapid, modified oxidase test for oxidase-variable bacterial isolates." Journal of clinical microbiology. vol. 16. 1982, pp. 772-774.

9. J.M. Miller, and J.W. Wright, "Spot indole test: evaluation of four reagents." Journal of clinical microbiology. vol. 15.1982, pp.59-592.

10. A.L. Barry, K.L. Bernsohn, A.P. Adams, and L.D. Thrupp, "Improved 18-hour methyl red test." Appl. environ. microbiol. vol. 20. 1970, pp. 866-870.

11. C.H. Werkmann, "An improved technic for the voges-proskauer test." Journal of bacteriology. vol. 20. 1930, pp. 121

12. T.N.S. Raghavachari, "The applicability of koser's citrate utilization test to sanitary water analysis in India." Indian journal of medical research vol. 14. 1926, pp.47-51.

13. Z. Ouyang, T. Wei, L. Huang, Z. Wang, Y. Zhang, W. Cai, S. Huang, J. Deng, Y. Sun, T. Li and Q. He, "Antimicrobial susceptibility of bacteria selected by Kirby-bauer method." Journal of food safety and quality. vol. 9.2018 , pp. 6500-6507.

\section{AUTHORS PROFILE}

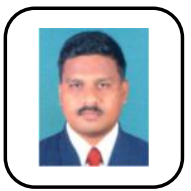

S. Sheik Asraf is an assistant professor working in KARE. He had completed his Ph.D. thesis in microbiology in Madurai Kamaraj University. His research interests include in the broad fields of advanced bioinformatics, metagenomics and inanimate microbiology. $\mathrm{He}$ is a beneficiary of JRF from DST, India. He has received travel awards from UNESCO, ICGEB, NSF, IUBMB, RCBTE, IUSSTF and DBT for participation in events held in India. He has published 25 conference/seminar/symposium abstracts, 3 chapters in books and 9 publications in journal. His present research focus is study of inanimate objects by metagenomics and culture dependent methods.

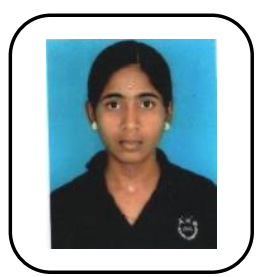

N. Shobi had completed her B. Tech Biotechnology from KARE. Her B. Tech. Project is entitled "Culture dependent study of microbiota of commercially available bar chochlates".

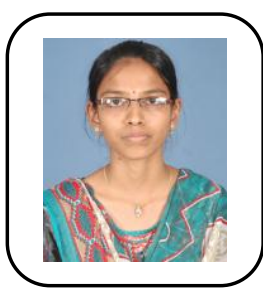

R. Soundarya had completed her B. Tech. Biotechnology from Kalasalingam Academy of Research and Education. Her B. Tech. Project is entitled "Culture dependent study of microbiota of commercially available bar chochlates".

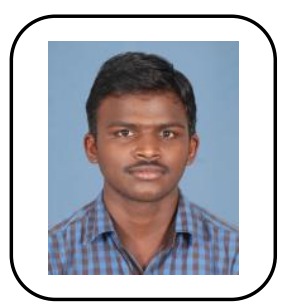

M. Udaya Kumar had completed his B. Tech Biotechnology from KARE. His B. Tech. Project is entitled "Culture dependent study of microbiota of commercially available bar chochlates". 